\title{
PENYULUHAN DAN PELATIHAN BUDIDAYA UBI KAYU DI DESA BAH DAMAR KECAMATAN DOLOK MARAWAN KABUPATEN SERDANG BEDAGAI
}

\author{
Iwan Hasrizart ${ }^{1 *}$, Asmara Sari Nasution ${ }^{2}$ \\ ${ }^{1,2}$ Agroteknologi, Fakultas Pertanian, Universitas Al-Azhar, Jl. Pintu Air IV No.214 Kwala Bekala \\ Padang Bulan Medan \\ *hasrizart68@gmail.com
}

\begin{abstract}
ABSTRAK. Masyarakat Desa Bah Damar Kecamatan Dolok Marawan Kabupaten Serdang Bedagai, mayoritas berprofesi sebagai petani tanaman pangan dan hortikultura, tanaman ubi kayu merupakan tanaman utama setelah tanaman jagung. Produksi tanaman ubi kayu di desa Bah Damar produktif tasnya masih sangat rendah sehingga sangat memungkin untuk ditingkatkan. Peningkatan hasil panen ubi kayu dapat dilakukan dengan memperbaiki teknik budidaya seperti menggunakan pemilihan bibit unggul dan pemupukan yang tepat. Dengan meningkatnya produktivitas tanaman ubi kayu, maka meningkat pula kesejahteraan masyarakat di desa Bah Damar. Tujuan dari pengabdian masyarakat ini adalah memberikan penyuluhan dan pelatihan kepada masyarakat tentang teknik budidaya tanaman ubi kayu yang baik dan benar dan selanjutnya dilakukan pelatihan teknik budidaya dan penggunaan pupuk yang benar. Setelah itu tetap dilakukan pembinaan dan pengawasan secara kontinu dari semua aktivitas budidaya tanaman ubi kayu. Hasil yang diperoleh masyarakat desa Bah Damar sudah mengetahui dan memahami tentang teknik budidaya ubi kayu dan mengerti betapa pentingnya pemupukan yang baik dan benar.
\end{abstract}

Kata kunci: Budidaya ubi kayu, klon unggul pemupukan.

ABSTRACT. The people of Bah Damar Village, Dolok Marawan District, Serdang Bedagai Regency, the majority of whom work as farmers of food crops and horticulture, cassava is the main crop after corn. The productivity of cassava in Bah Damar village is still very low, so it is possible to increase it. Increasing the yield of cassava can be done by improving cultivation techniques such as using the selection of superior seeds and proper fertilization. With the increase in the productivity of cassava plants, the welfare of the people in Bah Damar village also increases. The purpose of this community service is to provide counseling and training to the community about good and correct cassava cultivation techniques and then training in cultivation techniques and the correct use of fertilizers. After that, continuous guidance and supervision of all cassava cultivation activities is carried out. The results obtained are that the people of Bah Damar village already know and understand about cassava cultivation techniques and understand the importance of good and correct fertilization

Keywords: Cultivation of cassava, superior clones of fertilization.

Terima 12 Januari 2022 Terima dan di revisi 15 Januari 2022 Disetujui 17 Januari 2022

\section{PENDAHULUAN}

Tanaman ubi kayu (Manihot utilissima) sering juga disebu dengan singkong, ketela pohon, cassava, dll (Pramudita et al. 2014). Peranan ubi kayu sebagai penyangga sumber karbohidrat bagi kebanyakan masyarakat di pedesaan sekaligus sebagai sumber penghasilan yang menopang perekonomian mereka (Dinas Pertanian Buleleng, 2020).

Permintaan ubi kayu dari tahun ke tahun mengalami peningkatan, baik untuk pemenuhan kebutuhan pangan maupun industri. Peran ubi kayu dalam bidang industri akan terus mengalami peningkatan seiring dengan adanya program pemerintah untuk menggunakan sumber energi alternatif yang berasal dari hasil pertanian (liquid biofuel), seperti biodiesel dan bioetanol serta diversifikasi pangan berbasis pangan lokal (Sundari, 2010).

Ubi kayu mengandung kalori dan karbohidrat tinggi. Maka dari itu, singkong bisa jadi pilihan bahan makanan pokok pengganti nasi. 
Kalori yang terkandung pada singkong lebih tinggi ketimbang umbi-umbian yang lain. Ubi kayu terbukti berperan penting sebagai penyangga pangan bagi masyarakat pedesaan di Indonesia, khususnya sebagai bahan baku berbagai industri pangan dan non-pangan untuk keperluan dalam negeri maupun ekspor (Saleh Nasir, dkk. 2016). Produksi ubi kayu di tanah air cenderung tidak stabil kadang naik dan kadang turun hal ini disebabkan ketersediaan lapangan kerja, jika lapangan kerja tersedia minat petani untuk menanam ubi kayu cenderung berkurang dan sebaliknya jika lapangan kerja tidak ada atau sedikit masyarakat desa menanam ubi kayu. Simatupang (2012) melaporkan bahwa neraca perdagangan untuk beberapa produk berbasis ubikayu (tepung ubikayu, pati, dextrin) pada tahun 2011 menunjukkan defisit. Bahkan ditegaskan bahwa sebetulnya mulai tahun 2010, Indonesia sudah menjadi negara pengimpor produk berbasis ubikayu. Indonesia adalah penghasil ubi kayu terbesar keempat setelah Nigeria, Republik Demokratik Kongo, dan Thailand (FAOSTAT, 2017). Meskipun produksi di Indonesia termasuk 5 besar dunia dengan produk hilir yang beragam, namun pada kenyataannya impor ubi kayu di negara ini masih terbilang tinggi. Total impor produk ubi kayu segar dan olahan pada tahun 2017 dan 2018 tercatat rata-rata mencapai 382.000 ton (BPS, 2019). Produktivitas ubi kayu harus ditingkatkan. Peningkatan ini bisa melalui beberapa cara atau strategi salah satunya adalah dari teknik budidaya. Umumnya masyarakat belum melakukan budidaya ubi kayu dengan maksimal, tanaman ubi kayu merupakan tanaman sampingan, belum merupakan tanaman utama (Anindita, 2017).Ubi kayu termasuk bahan pangan yang dapat diolah dengan berbagai bentuk olahan pangan yang sangat diminati oleh masyarakat luas. Sehingga produksi ubi kayu perlu ditingkatkan.

Peringatkan produktivitas ubi kaya dapat ditingkatkan dengan pemberian pupuk yang berimbang serta penambahan pupuk kandang atau pupuk organik, (Prado dkk., 2011).

Kecukupan unsur hara tanaman ubi kayu dapat diperoleh melalui pemupukan dengan menggunakan pupuk anorganik (kimia) maupun pupuk organik (pupuk kompos, dan pupuk kandang). Pupuk organik mempunyai fungsi penting bagi tanah yaitu untuk menggemburkan lapisan tanah permukaan (top soil), meningkatkan populasi jasad renik tanah, memper tinggi daya serap dan daya simpan air yang secara keseluruhan akan meningkatkan kesuburan tanah (Atmojo, 2006). Unsur hara esensial adalah suatu unsur hara yang ketersediaannya harus ada dan tercukupi bagi pertumbuhan tanaman dan fungsinya tidak dapat digantikan oleh unsur lain (Hartatik dan Widowati, 2006). Unsur hara essensial ini tidak tersedia dan tidak tercukupi bagi tanaman, maka akan berakibat tanaman tidak dapat menyelesaikan siklus hidupnya, dalam artian pertumbuhannya terhambat. Unsur hara esensial ini terbagi lagi atas unsur hara makro dan unsur hara mikro (Prado dkk., 2011). Pengelolaan hara spesifik lokasi beru paya menyediakan hara bagi tanaman secara tepat, baik jumlah, jenis, maupun waktu pemberiannya, dengan mempertimbangkan kebutuhan tanaman, dan kapasitas lahan dalam menyediakan hara bagi tanaman (Farhad dkk., 2010).

\section{METODE}

Dari hasil laporan, informasi tentang teknik budidaya ubi kayu yang ditekuni oleh masyarakat desa Bah Damar Kecamatan Dolok Marawan Kabupaten Serdang Bedagai. Serta di dukung oleh data yang telah diperoleh secara langsung di lapangan, di tengah tengah masyarakat sehingga permasalahan dapat diidentifikasi kan permasalahan tentang cara budidaya ubi kayu yang belum maksimal yang dilakukan oleh sebagian besar masyarakat petani ubi kayu di desa Bah Damar kecamatan dolok merawan kabupaten Serdang bedagai adalah. Maka dilakukan beberapa hal yang dapat meningkatkan produksi ubi kayu di desa tersebut yaitu:

1. Ceramah Penyuluhan teknik budi daya ubi kayu yang baik dan benar. Penyuluhan dan pelatihan secara kontinu berkelanjutan dan intensif tentang bagaimana cara memilih bibit yang baik pengolahan tanah, pemupukan yang berimbang antara pemberian pupuk kimia dan pupuk organik (pupuk kandang).

2. Pelatihan dan praktik teknik budi daya ubi kayu yang baik dan pelatihan secara kontinu berkelanjutan dan intensif tentang bagaimana cara memilih bibit yang baik pengolahan tanah, pemupukan yang berimbang antara pemberian pupuk kimia dan pupuk organik (pupuk kandang). 
3. Melaksanakan monitoring dan evaluasi kegiatan, setelah selesai seluruh kegiatan penyuluhan dan pelatihan, setelah itu di tidak lanjuti dengan melihat hasilnya, Hasil evaluasi menjadi dasar untuk perbaikan selanjutnya

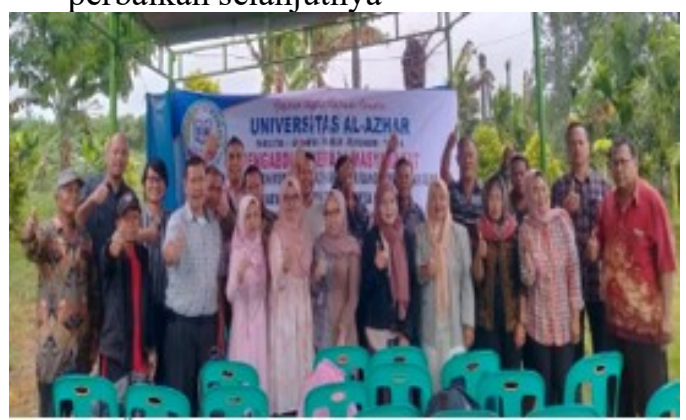

Gambar 1 aktivitas penyuluhan (Sumber: data diolah, 2021)

\section{HASIL DAN PEMBAHASAN}

Sesuai dengan metode pelaksanaan kegiatan pengabdian kepada masyarakat $(\mathrm{PkM})$ telah dilaksanakan beberapa kegiatan antara lain penyampaian isi materi, ceramah, tanya jawab dan praktik pelaksanaan budidaya tanaman ubi kayu yang baik dan benar. Pelaksanaan yang telah dilaksanakan adalah:

a. Budidaya ubi kayu

b. Pemberian pupuk kimia yang berimbang

c. Pemberian pupuk kandang

Ceramah dan diskusi bertujuan untuk memberikan informasi dan ilmu pengetahuan tentang bagaimana cara budidaya ubi kayu, pemupukan yang berimbang dan pentingnya penggunaan pupuk kandang dalam pertanian kepada masyarakat Desa Bah Damar Kecamatan Dolok Marawan Kabupaten Serdang Bedagai.

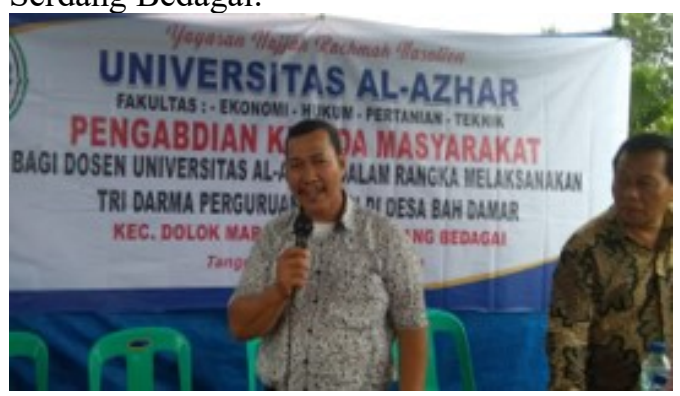

Gambar 2 tanya jawab (Sumber: data diolah, 2021)

Langkah awal kegiatan (PkM) ini yaitu menjelaskan kepada Masyarakat bagaimana cara memilih bibit ubi kayu yang baik/bagus, pengolahan tanah, pemberian pupuk dasar yaitu pemberian dan pencampuran pupuk kandang dengan tanah bersamaan dengan pengolahan tanah, pemberian pupuk yang tepat seperti tepat waktu dan tepat dosis.

Dalam ceramah ini, juga dilakukan tanya jawab ataupun diskusi tentang kendala yang selalu dihadapi oleh masyarakat dalam melakukan penanaman ubi kayu. Seperti kebiasaan kebiasaan dan opini, mereka. Seperti anggapan masyarakat jika tanaman ubi kayu diberikan pupuk, akan mempengaruhi kualitas ubi kayu seperti, rasa tidak enak dan cepat busuk. Atau jika diberikan pupuk kandang akan banyak tumbuh rumput (gulma).

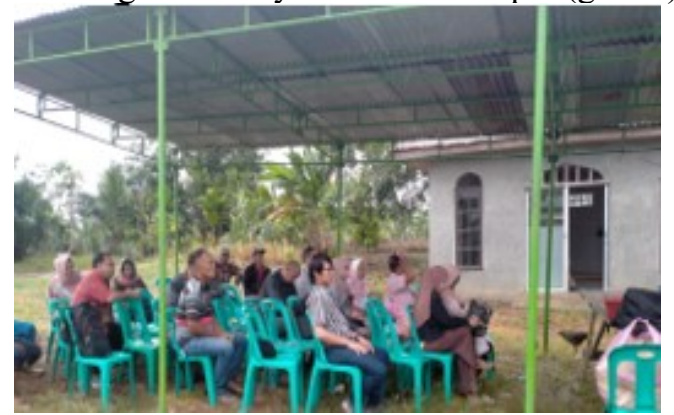

Gambar 3 Lokasi penyuluhan (Sumber: data diolah, 2021)

Dari hasil diskusi dan ceramah tentang teknik budidaya tanaman ubi kayu, terlihat semangat dan antusias petani untuk bersungguh sungguh dalam menanam ubi kayu di masa masa yang akan datang. Karena tanaman ubi kayu ini dapat kita harapkan sebagai sumber pendapatan utama bagi masyarakat khususnya masyarakat desa Bah Damar Kecamatan Dolok Marawan Kabupaten Serdang Bedagai. Kegiatan pengabdian masyarakat ini diharapkan menjadikan kegiatan yang berkelanjutan, karena petani/masyarakat akan tetap dipantai sampai mereka berhasil dan dievaluasi, sehingga petani tidak lagi mengalami kesulitan untuk penanganan pasca panen. Dari hasil monitoring dan evaluasi masyarakat sangat terbantu selain dari sisi budidaya tanaman ubi kayu, pengolahan tanah, menentukan waktu panen yang tepat dan penanganan panen dan pasca panen sehingga masyarakat benar benar menguasai teknik budidaya ubi kayu sampai ke pemasarannya. Disamping itu juga hasil olahan ubi kayu sangat beragam dan pulang bisnisnya terbuka lebar sehingga sangat peluang atau prospek budidaya ubi kayu ini sangat menjanjikan dan bisa diandalkan untuk menopang perekonomian masyarakat. Praktik budidaya tanaman ubi kayu 
Dalam pelaksanaan praktik budi daya tanaman ubi kayu, telah dilaksana kan secara langsung ke lahan masyarakat dengan menunjukkan bagai mana jenis dan ciri ciri bibit stek yang baik dan berasal dari batang ubi kayu yang unggul, kemudian dilanjutkan dengan pemberian pupuk kandang ditabur ke permukaan tanah, setelah itu dilanjutkan dengan pengolahan tanah sehingga pupuk kandang tercampur dengan merata di seluruh permukaan tanah. Setelah itu melakukan penanaman bibit ubi kayu yang telah dipersiapkan.

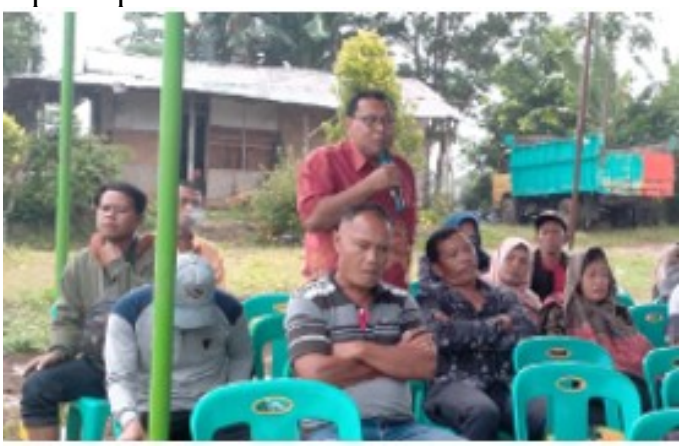

Gambar 4 tanya jawab (Sumber: data diolah, 2021)

\section{SIMPULAN}

1. Hasil pemberian pupuk dan telah dicampur secara merata di lahan pertanian dapat dilihat bahwa tanahnya semakin gembur dan terjadi perubahan warna menjadi ke hitam hitaman. Dalam hal penanaman bibit ubi kayu lebih mudah di tancapkan, sehingga bisa memudahkan dalam menentukan ke dalam bibit ubi kayu ditancapkan ke dalam tanah/lahan.

2. Tanaman ubi kayu ini dapat kita harapkan sebagai sumber pendapatan utama bagi masyarakat khususnya masyarakat desa Bah Damar Kecamatan Dolok Marawan Kabupaten Serdang Bedagai

\section{UCAPAN TERIMAKASIH}

Terima kasih kami ucapkan kepada Ibu rektor Universitas Al Azhar, yang telah mendukung acara ini sehingga berjalan dengan mulus. Begitu juga kepada rekan rekan sejawat yang tergabung dalam satu TIM besar pengabdian kepada Masyarakat. Tidak lupa juga ucapan terima kasih kepada Bapak Anggota Dewan yang telah mendukung dan memfasilitasi acara ini, Terimakasih kami ucapkan Pejabat
Pemerintahan, yang telah berkenan untuk hadir dalam acara tersebut. Terima kasih kami ucapkan Bapak Kepala desa dan perangkatnya, serta kepada seluruh masyarakat masyarakat Desa Bah Damar Kecamatan Dolok Marawan Kabupaten Serdang Bedagai. Yang telah ikut mendukung dan berpartisipasi dalam acara ini sehingga acara ini berjalan lancar, sesuai dengan yang diharapkan.

\section{DAFTAR PUSTAKA}

Dinas Pertanian Buleleng. 2020. Bertanam ubi kayu yang menguntungkan, https://distan,bule-

lengkab.go.id/informasi/detail/artikel/bert anam-ubikayu-yang-menguntungkan-64

Sundari Titik. 2010. Pengenalan Varietas Unggul dan Teknik Budidaya Ubi kayu (Materi Pelatihan Agribisnis bagi KMPH) Balai Penelitian Kacang Kacangan dan Umbi Umbian, Malang Report No. 55.STE.Final

Irawan Ade, 2019. Cara Menanam Ubi Kayu Yang Baik Dan Benar.http://cy bex.pertanian.go.id/mobile/artikel/84962/ Cara-Menanam-Ubi-Kayu-Yang BaikDan-Benar/

Saleh Nasir, Abdullah, T, Yudi W, Yudi W, Titik S. 2016. Pedoman Budi Daya Ubi Kayu Di Indonesia Indonesian Agency For Agricultural Research And Development (Iaard) Press

Pramudita,H.M., W.H. Utomo, dan S. Prijono. 2014. Implementasi pemeli haraan lahan pada tanaman ubikayu: Pengaruh pengelolaan lahan terhadap hasil tanaman dan erosi. J. Tanah dan Sumberdaya Lahan 1(2): 88-92

Simatrupang, P. 2012. Meningkatkan daya saing ubikayu, kedelai dan kacang tanah untuk meningkatkan penda patan petani, ketahanan pangan, nilai tambah, dan penerimaan devisa. p. 1-12. Dalam: Prosiding Seminar Nasional Hasil Penelitian Tanaman Aneka Kacang dan Umbi tahun 2012. Puslitbangtan Bogor.

Anindita R, Fitrotul. L, Nur. B, 2017. Pola Konsumsi Ubi Kayu Indonesia, Program Studi Agribisnis, Jurusan Sosial Ekonomi Fakultas Pertanian Universitas Brawijaya Jalan Veteran - Malang 65145 
Prado, R.M. dan Vara, E.A. 2011. Tolerance to Iron Chlorosis in Non-Grafted Quince Seedlings and in Pear Grafted Onto Quince Plants. Journal of Soil Science and Plant Nutrition. 11 (4): 119-128.

Atmojo, S.W. 2006. Peranan Bahan Organik terhadap Kesuburan Tanah dan Upaya Pengelolaannya. Sebelas Maret University Press. Surakarta.

Hartatik, W. dan Widowati, L.R. 2006. Pupuk Kandang. http://balittanah.lit bang. pertanian.go.id/ind/dokumentasi/lainnya/ 04pupuk\%20kandang.pdf 